湿潤状態での岩石の一軸圧縮強度の載荷速度依存性
大久保 誠介* 西 松 裕 一 $^{*}$
何 昌 栄** 秋 晳 淵***

\title{
Loading Rate Dependency of Uniaxial Compressive Strength of Rock Under Water-Saturated Condition
}

\author{
by
Seisuke Okubo*, Yuichi Nishimatsu*, C. HE** and Se jk Yuen $\mathrm{CHU}^{* * *}$

\begin{abstract}
Moisture has various effects on the beheviour of rocks. It is well known that the compressive strength decreases significantly with an increase of moisture content. Though many studies have been carried out concerning the effect of moisture, the influence on the time dependent behaviour is still open to discussion. It is very important to clarify its time dependence for analysing the long-term stability or durability of underground structures.

In this study, six rocks were tested in uniaxial compression under four loading rates $C=10^{-6}, 10^{-5}$, $10^{-4}$ and $10^{-3} / \mathrm{sec}$. With an increase of loading rate, it was found for all samples that the strength increased and the stress-strain curve in the post-failure region shifted to the right-hand side. The slope of the stress-strain curve, however, did not change meaningfully with loading rate. It should be noted that the increase of strength with loading rate did not depend on moisture content.

The constitutive equation which is applicable to various time dependent behaviours was used to simulate the loading rate dependence under uniaxial compression tests. It was found that the calculated results gave a good approximation to the experimental results for all sample rocks.
\end{abstract}

Key words : Rock, Compressive strength, Moisture, Time dependence, Visco-elasticity

\section{1 はじめに}

岩石の強度は，気乾状態と湿潤状態とで相当に異な ることが知られている. 例えば, Colbak ら゙は湿度が 増加すると頁岩や砂岩の圧縮強度が顕著に低下するこ とを示した. Vutukuri らは従来の研究をまとめたが, その結果を見ると岩石の強度は水分によって左右され るが，その程度は岩石ごとに異なる．岩石の力学的性 質に及ほすす水の影響は，その後も多くの研究者により 取り挙げられたが, 多くは単に標準的な載荷速度で試 験を行なった時の強度を報告しているのみであり，そ の機構を検討する際に重要な時間依存性挙動に及ぼす 水の影響についての研究は少ない. Kirby は, 水の及 ぼす化学的影響の特集号の初めで, 水分の影響は複雑 であり，種々の機構が複雑に関連し合っていると述べ ている. 有力な機構の一つとして, 応力腐食があり, Anderson ら゙はこれについてまとめているが, 取り挙 げられている重要な実験結果はガラスとかアルミナを 用いたものが多い。
従来の研究結果より, 水が岩石の力学的性質に相当 な影響を及ぼすことはわかっているが，一歩進んでそ の機構を論じようとすると根拠とすべき実験結果が不 足している．例えば，下記のような基礎的とも思われ る事項についても不明な点が多い.

(1) 完全応力-ひずみ線図は気乾状態と湿潤状態と でどのように異なるか.

（2）時間依存性挙動の一つである強度の載荷速度依 存性はどのように異なるか.

そこで, 本研究ではこれらの基本的な事項を明らか にする為, 気乾状態および湿潤状態で, 載荷速度を変 えた一軸圧縮試験を数種の岩石を用いて行なった．さ らに，構成方程式により実駼結果を再現することを試 みた。これは，以前気乾状態の岩石を対象として提案 した構成方程式の適用範囲を湿潤状態にまで搪張する 試みであると共に, 構成方程式中のパラメータの差異 より, 気乾状態と湿閏状態との差異を検討したかった ためである。

\footnotetext{
$\dagger \quad$ 原稿受理 平成 3 年 6 月 24 日 Received June 24,1991

* 正会 員 東京大学工学部資源開発工学科 $\bar{T} 113$ 東京都文京区本郷, Dept. of Mineral Dev. Eng., The University of Tokyo, Bunkyo-ku, Tokyo, 113

** 中国国家地震局地質研究所 中国北京, Inst. of Geology, State Seismological Bureau, Beijing, China

*** 東京大学大学院 $=113$ 東京都文京区本郷, Graduate Student, The University of Tokyo, Bunkyo-ku, Tokyo, 113
} 


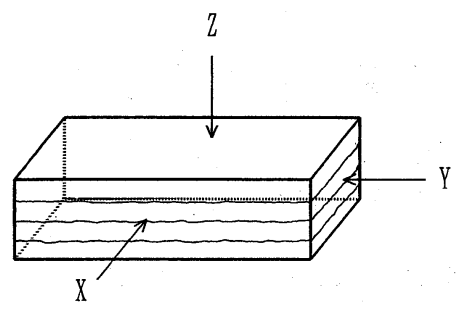

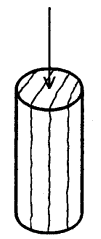

$\mathrm{X}$

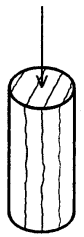

Y

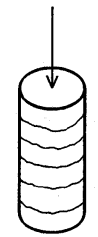

2
Fig. 1. Flow structure of Sanjome andesite and loading directions in uniaxial compression test.

\section{2 実験方法と資料岩石}

試験機としては容量 $10 \mathrm{t}$ と $150 \mathrm{t}$ の 2 台の油圧式サ 一ボ試験機を用い，クラス I 岩石は定ひずみ速度で, クラス II 岩石は次式であらわされる応力帰還制御で試 験を行なった。

$$
\varepsilon-(\alpha / E) \sigma=C \cdot \mathrm{t}
$$

ただし， $\alpha$ は応力帰還量を決める常数， $E$ はヤング 率, $C$ は載荷速度である. 試験室は $20 \pm 5^{\circ} \mathrm{C}$, 湿度 $65 \pm 15 \%$ に保たれており，以下で言う気乾状態とは， 試験片整形後 1 力月以上試験室で自然乾燥させた後試 験をした場合であり，湿潤状態とは 1 カ月以上水中に 放置してから試験をした場合である。なお，水は市販
のイオン交換による清浄水をしばらく空気中に放置し, $\mathrm{pH}$ が 5.7 前後となり以降ほとんど変わらなくなって から試験に供した。

今回使用した岩石は次に挙げる 6 種類である. 稲田花こう岩 ○河津凝死岩 ○三城目安山岩 $\mathrm{A}$ 三城目安山岩 B $\bigcirc$ 田下凝兏岩 ○大谷凝兏岩 いずれも，同一のブロックより試験片を製作して一連 の実験を行なった。試験片は, 直径 $2.5 \mathrm{~cm}$ で高さ $5 \mathrm{~cm}$ とし, 端面の平行度は $\pm 0.02 \mathrm{~mm}$ 以内である. なお，三城目安山岩 B については比較的流離面が顕 著であったので Fig. 1 に示すように 3 方向より試験片 を切り出して使用した。

\section{3 実 験 結 果}

Table I には各岩石の密度，空げき率，ヤング率， 一軸圧縮強度をまとめて示した。 また, Fig. 2 に載荷 速度 $10^{-5} / \mathrm{sec}$ の時の気乾状態と湿潤状態での応力ひずみ線図を実線で示した．なお，稲田花こう岩の場 合には気乾状態と湿潤状態との差が小さいため，気乾 状態での応力ーひずみ線図のみ示した.

稲田花こう岩の応力ーひずみ線図は最初の内ほぼ直 線であるが, $150 \mathrm{MPa}$ 付近より次第に傾きが小さく なりやがて強度破壊点に到達する。強度破壊点に到達 した後は応力は急激に下がり，線図は正の傾きを持つ ようになる。この傾向は気乾状態と湿潤状態とで変わ らず，湿潤状態での強度がわずかに小さいだけで応力 一ひずみ線図の形状はほぼ同一であった。なお，花こ う岩ではたて割れが試験片内部で順次進展して破壊に 至ると考えられ，強度破壊点を過ぎた辺りより試験片 側面には載荷軸方向のき裂が観察できるようになり， やがて試験片の側面より長さ数 $\mathrm{mm}$ から $1 \mathrm{~cm}$ の薄片

Table I. Mechanical properties of rocks.

\begin{tabular}{|c|c|c|c|c|c|c|c|c|}
\hline & & & $\begin{array}{l}\text { Specific } \\
\text { gravity }\end{array}$ & $\begin{array}{c}\text { Porosity } \\
\text { (\%) }\end{array}$ & $\begin{array}{c}\text { Young's } \\
\text { modulus: } \\
\text { (GPa) }\end{array}$ & $\begin{array}{c}\text { Reduction } \\
\text { (\%) }\end{array}$ & $\begin{array}{c}\text { UCS* } \\
(\mathrm{MPa})\end{array}$ & $\begin{array}{c}\text { Reduction } \\
\text { (\%) }\end{array}$ \\
\hline \multirow[t]{2}{*}{ Inada } & Granite & Air-dried & 2.61 & & 40.0 & & 190 & \\
\hline & & Water-saturated & 2.63 & 2.1 & 40.0 & 0.0 & 184 & 3.3 \\
\hline \multirow[t]{2}{*}{ Kawazu } & Tuff & Air-dried & 1.92 & & 6.6 & & 33 & \\
\hline & & Water-saturated & 2.22 & 29.8 & 5.3 & 19.9 & 23 & 34.0 \\
\hline \multirow[t]{2}{*}{ Sanjome } & Andesite A & Air-dried & 2.16 & & 11.7 & & 94 & \\
\hline & & Water-saturated & 2.31 & 15.4 & 10.9 & 4.6 & 73 & 21.8 \\
\hline \multirow[t]{7}{*}{ Sanjome } & Andesite B & & & & & & & \\
\hline & $\mathrm{X}$-direction & Air-dried & 2.15 & & 9.5 & & 88 & \\
\hline & & Water-saturated & 2.31 & & 8.7 & 8.2 & 67 & 23.4 \\
\hline & Y-direction & Air-dried & 2.16 & & 9.6 & & 88 & \\
\hline & & Water-saturated & 2.32 & 16.8 & 8.8 & 8.2 & 68 & 22.2 \\
\hline & Z-direction & Air-dried & 2.16 & & 9.6 & & 88 & \\
\hline & & Water-saturated & 2.31 & & 8.8 & 7.5 & 70 & 20.9 \\
\hline \multirow[t]{2}{*}{ Tage } & Tuff & Air-dried & 1.81 & & 3.4 & & 15 & \\
\hline & & Water-saturated & 2.04 & 24.6 & 3.1 & 33.5 & 8 & 45.0 \\
\hline \multirow[t]{2}{*}{ Oya } & Tuff & Air-dried & 1.43 & & 2.6 & & 11 & \\
\hline & & Water-saturated & 1.76 & 33.9 & 1.3 & 48.8 & 5 & 56.8 \\
\hline
\end{tabular}

* Uniaxial compression strength. 


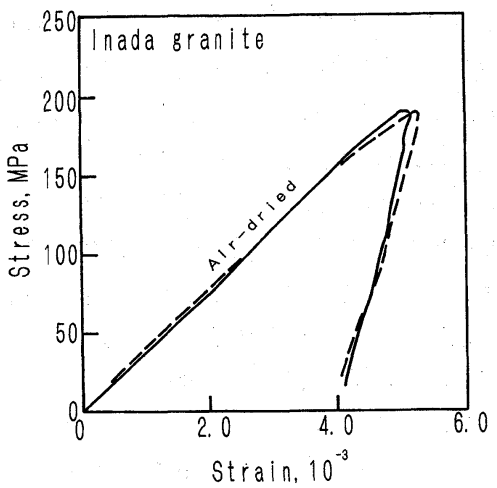

(a) Inada Granite

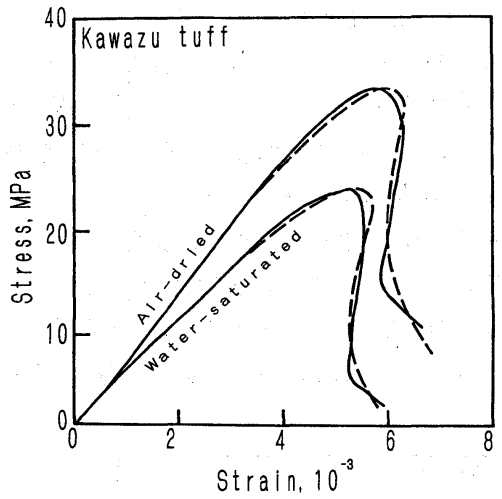

(b) Kawazu Tuff.

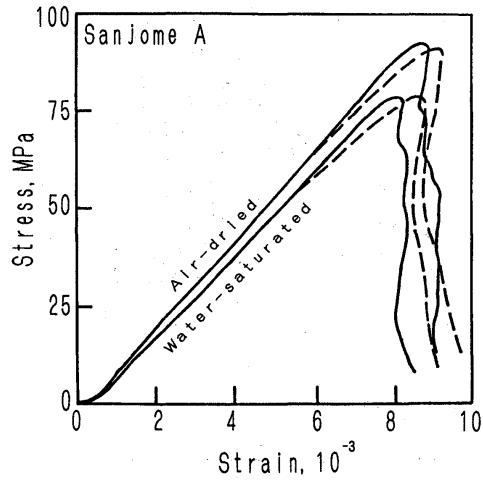

(c) Sanjome Andesite A.

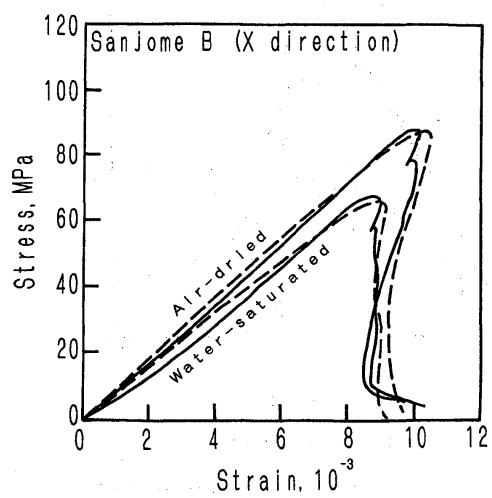

(d) Sanjome Andesite B (X-direction)
が多数はく離して落ちる.

河津凝灰岩では，強度破壊点付近の応力ーひずみ線 図が花こう岩に比べ丸みを帯びている，強度破壊点を 過ぎた後急激に応力が低下するが，強度の 20 から $40 \%$ まで低下すると応力の低下は緩やかになり線図 も緩やかな負の傾きを持つようになる．ちょうどこの 前後より, 試験片を斜めに横切るせん断き裂が観察で きるようになる．以上のことは気乾状態でも湿潤状態

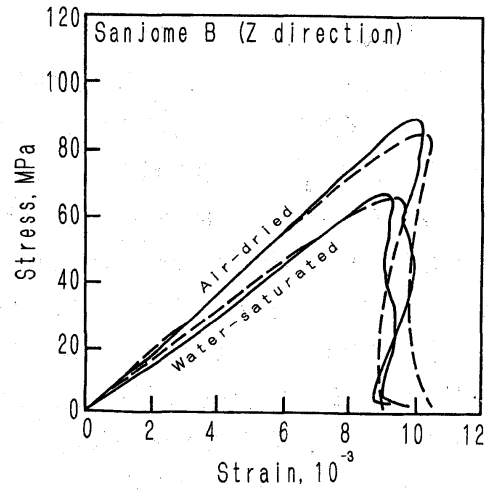

(e) Sanjome Andesite B (Z-direction).

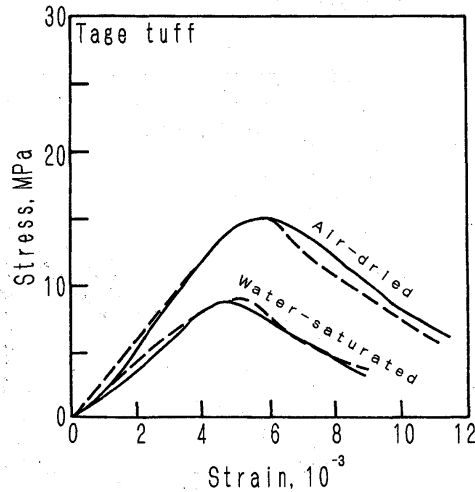

(f) Tage Tuff.

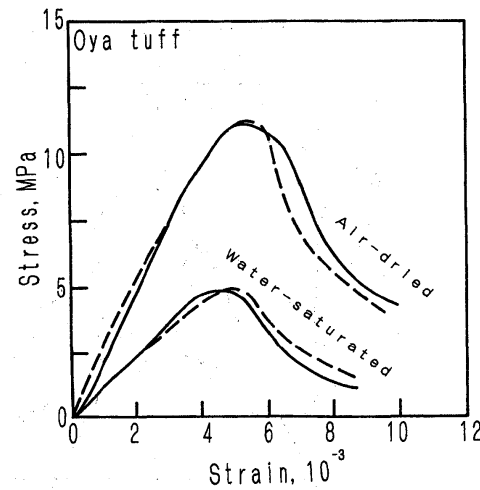

(g) Oya Tuff.

Fig. 2. Stress-strain curves at loading rate $10^{-5}$ per second in air-dried and water-saturated conditions. Solid and dotted lines are experimental and calculated results, respectively. 
でも言える．湿潤状態では気乾状態に比べてヤング率 が $20 \%$ 程度, 強度が $30 \%$ 程度低下するので, 気乾状 態での応力ーひずみ線図が湿潤状態でのそれを内包す る.

三城目安山岩 A と B は別途購入したもので，Aの 方が強度が高い：なお，A は Z 方向に載荷した実験 のみを行なった。 Bでは Fig. 1 に示した 3 方向より載 荷した実験を行なったが $\mathrm{X}$ 方向と $\mathrm{Y}$ 方向の結果は類 似していたので，Y 方向の結果は示さない、いずれ の場合も，強度破壊点付近の丸みは花こう岩よりは大 きく，河津凝灰岩よりは小さく，両者の中間と言える. 強度破壊点以降の線図は，平均的に見ればほぼ応力軸 に平行である. $\mathrm{B}$ の強度破壊点以降の $\mathrm{X}$ 方向や $\mathrm{Y}$ 方 向の線図では，応力が強度の $80 \%$ となった付近で, いったん応力の上昇する部分か観察された。この現象 には再現性があり，Z 方向に載荷した時には観察さ れない，以上のことがらは気乾状態でも湿潤状態でも 言える，湿潤状態では気乾状態に比べて強度が $20 \%$ 程度低下すること，気乾状態の線図が湿潤状態のそれ を内包することは三城目安山岩 A，B ともに言える。

田下凝灰岩と大谷凝死岩とを比較すると，大谷凝灰

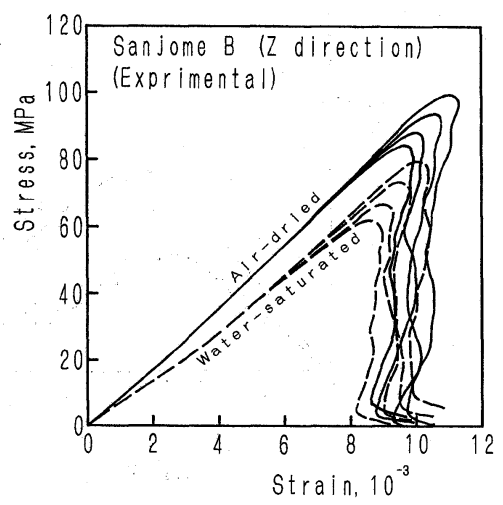

(a) Sanjome Andesite B (Experimental).

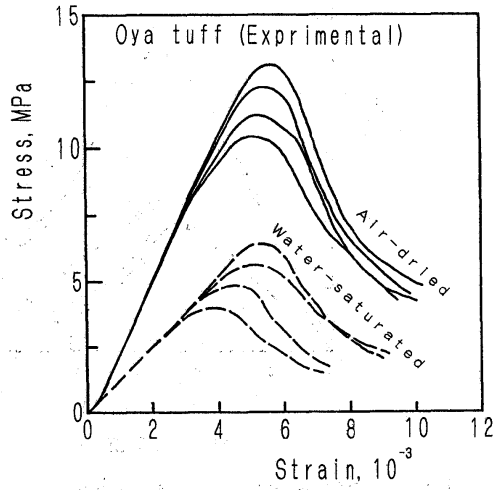

(c) Oya Tuff (Experimental)
岩の方が空げき率が高く強度が低い．強度破壊点まで の応力ーひずみ線図の形状は比較的似ているが，強度 破壞点以降では田下凝灰岩の方が緩やかな傾きを持っ ている．共に，明暸なせん断面が形成される．含水に よるヤング率の低下は田下凝灰岩で $35 \%$ ，大谷凝灰 岩で $50 \%$ 程度である．強度の低下は田下凝灰岩て $45 \%$ ，大谷凝灰岩で $55 \%$ 程度である。両岩石ともヤ ング率，強度が大きく低下すると言えよう，気乾状態 の応力ーひずみ線図が湿潤状態のそれを内包する傾向 は両者で見られた

Fig. 3 には，載荷速度 $C$ を $10^{-6}$ から $10^{-3} / \mathrm{sec}$ ま で変えた時の応力ーひずみ線図を, 三城目安山岩 B （Z 方向）と大谷凝灰岩を例に取って示した．いずれ の場合も, 載荷速度が速くなると強度は増し, 強度破 壊点でのひずみも増す. 両者とも, 載荷速度が 10 倍 となるごとに一定值ずつ増加する，気乾状態でも湿潤 状態でも, 載荷速度の速い時の応力-ひずみ線図が, 遅い時のそれを内包する。また，強度の变化に比べ， 載荷速度によるヤング率の変化はずっと小さい. Fig. 3 は 2 岩石の結果のみ示したが, 以上の事柄は今回実 験したすべての岩石に対して, 気乾状態, 湿潤状態を

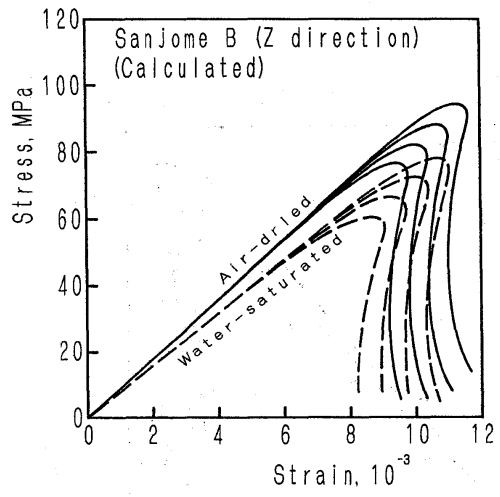

(b) Sanjome Andesite B (Calculated).

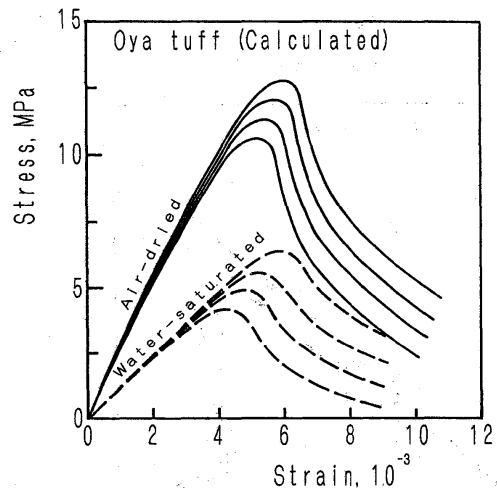

(d) Oya Tuff (Calculated)

Fig. 3. Experimental and calculated stress-strain curves under various loading rates. Loading rates are $10^{-3}, 10^{-4}, 10^{-5}$ and $10^{-6}$. per second from up to down. 


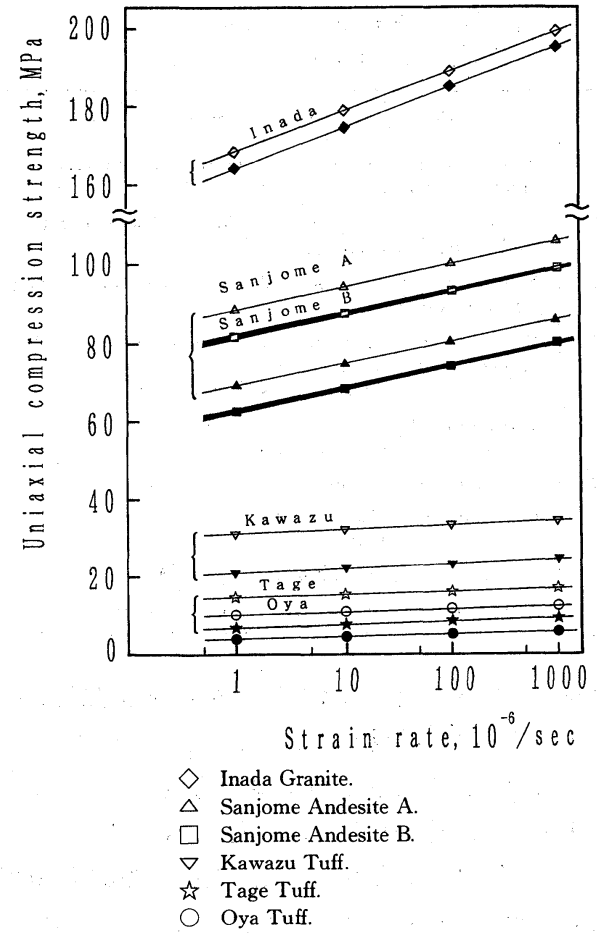

Fig. 4. Increase of uniaxial compressive strength with loading rate. Lines are obtained by the method of least squares. In case of Sanjome Andesite $\mathrm{B}$, three lines in $\mathrm{X}, \mathrm{Y}, \mathrm{Z}$ directions are on a thick line. Open symbol indicates results in air-dried condition, and rigid symbol in water-saturated condition. For example, $\diamond$ for Inada Granite in air-dried condition, and $\diamond$ for Inada in water-saturated condition.

問わず共通して言える.

Fig. 4 には横軸に載荷速度の対数をとり，強度の変 化を岩石ごとに示した．いずれの岩石でも強度 $\sigma_{\mathrm{F}}$ は 載荷速度 $C$ の対数に比例して増加しており, 次式で 近似できる。

$$
\sigma_{\mathrm{F}}=\frac{\text { Const. }+\ln (C)}{\delta}
$$

また，興味深いことにその傾き $1 / \delta$ は気乾状態と湿 潤状態とでほぼ一致している。.すなわち，載荷速度が 10 倍となるごとに強度は一定值 $\Delta \sigma=\ln (10) / \delta$ だけ上 昇し，その值は気乾状態と湿潤状態とで変わらない. 湿潤状態の強度の方が小さいので，載荷速度が 10 倍 となった時の強度の増加率は, 気乾状態より湿潤状態 が大きいことになる．線形粘弾性モデルは破壊現象を 表現するのに適さずこの様な強度の載荷速度を説明で きないし，非線形粘弾性モデルでもこれを的確に再現 できるものは限られる。

\section{4 構成方程式を用いた検討}

\section{$4 \cdot 1$ 構成方程式}

ここでは，岩石の構成方程式と，その構成方程式を 用いた数值計算結果について述べるが，それに先立ち 構成方程式の具備すべき要件を明確にするため，実験 結果をまとめてみると次のようになる。

（1）載荷速度が 10 倍となるごとに強度が一定值 $\Delta \sigma$ ずつ増加する.

（2）載荷速度が上昇するとヤング率は上昇するが, その程度は強度の上昇よりずっと小さい，

（3）載荷速度が上昇しても応力ーひずみ線図の形状 はさほど変わらない。

載荷速度の大きい時の線図が，小さい時のそれを内 包する.

（4）気乾状態と湿潤状態とで， $\Delta \sigma$ の值は変わらな い.

（5）気乾状態と湿潤状態とで応力ーひずみ線図の形 状はさほど変わらない。

気乾状態の線図が，湿潤状態の線図を内包する.

これらの現象を良く再現できることが構成方程式の 要件であり, さらに次の点も要件として加えられる.

（6）クラス I，クラス II 岩石を問わず，強度破壊点 以降まで適用できる.

（7）クリープ挙動など他の時間依存性挙動にも適用 できる.

（8）パラメータを，比較的簡単に求めることができ る.

岩石の構成方程式は，すでに相当数提案されている ものの，多くは線形粘弾性論に基づいたものである 実験結果 (1) と (2) は非線形性の強いことを示唆してお り，線形粘弾性論に基づいた構成方程式は適用できな い. 非線形粘弾性論に基づいた構成方程式も最近いく つか提案されているが，その内 (6) から (8) の要件を満 たしている筆者の提案した次式で表される構成方程式 を基に検討することにする.

$$
\begin{gathered}
\varepsilon=\varepsilon 1+\varepsilon 2 \\
\varepsilon 1=\sigma / E \\
d \varepsilon 2 / d t=g(\sigma) \cdot f(\varepsilon 2)
\end{gathered}
$$

この構成方程式は基本的には，Fig. 5 に示すように, 線形弾性ばねと非線形の粘性要素を直列につないだも のである。 $\varepsilon 1$ は弾性ばねのひずみを， $\varepsilon 2$ は粘性要素 のひずみを表す. ヤング率（ばね常数）E は一定と

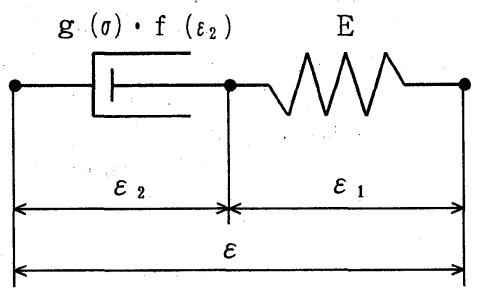

Fig. 5. Non-linear Maxwell model. 


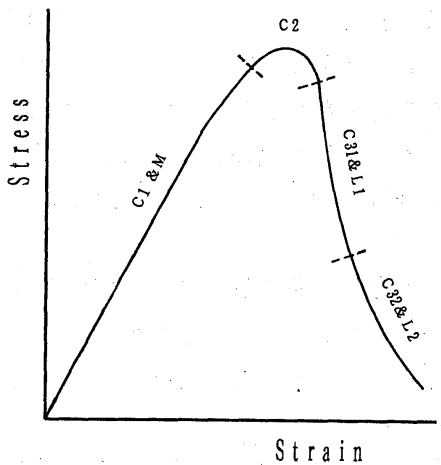

Fig. 6. Region where effect of each parameter in the constitutive equation is dominant.

している. 実際には破壊現象の進行と共に $E$ は変化 していくが，Eの変化によるひずみの増加も $\varepsilon 2$ の中 に含めている。これは, 粘性的なひずみの増加と, $E$ が減少した結果生ずるひずみの増加と実験的に分離す ることは相当に困難であるためである.

ここで, 式 $(3)$ 中の $g(\sigma)$ と $f(\varepsilon 2)$ を次のように仮定 する.

$$
\begin{aligned}
& g(\sigma)=\exp \left(\delta \cdot \sigma-\delta \cdot \sigma_{\mathrm{F} 0}\right) \\
f(\varepsilon 2)= & \mathrm{C} 1 \cdot \varepsilon 2^{-\mathrm{M}}+\mathrm{C} 2 \\
& +\mathrm{C} 31 \cdot \varepsilon 2^{\mathrm{L} 1}+\mathrm{C} 32 \cdot \varepsilon 2^{\mathrm{L} 2}
\end{aligned}
$$

$\delta$ : 常数, 載荷速度を 10 倍としたときの強度の増分

$$
\text { を } \Delta \sigma \text { とすると, } \delta=\ln (10) / \Delta \sigma
$$

$\sigma_{\mathrm{F} 0}$ : 載荷速度 $10^{-5} / \mathrm{sec}$ での一軸圧縮強度

以前提案した式との相違は, 式(4)をべき乗 $\sigma^{n} よ り$ $\exp$ としたこと, および式 (5) 右辺第 4 項を追加した

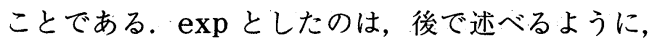
同じ值の $\delta$ を用いて気乾状態と湿潤状態の結果が説

\begin{tabular}{|c|c|}
\hline & Effect of Parameter to Calculated Results \\
\hline$E$ & $\begin{array}{l}\text { Slope of stress -strain curve in pre-failure region in- } \\
\text { creases with } E \text {. }\end{array}$ \\
\hline$\delta$ & $\begin{array}{l}\delta=\ln 10 / \Delta \sigma \text { where } \Delta \sigma \text { is the strength increase with } 10 \\
\text { fold increase of loading rate. }\end{array}$ \\
\hline $\mathrm{M}$ & $\begin{array}{l}\text { Stress-strain curve in pre-failure region becomes straight } \\
\text { when } M \text { is large. }\end{array}$ \\
\hline $\mathrm{L} 1$ & $\begin{array}{l}\text { Slope of stress-strain curve in post-failure region becom- } \\
\text { es steeper with increase of L1. } \\
\text { (at comparatively higher stress level) }\end{array}$ \\
\hline L2 & $\begin{array}{l}\text { Same with L1. } \\
\text { (at comparatively lower stress level) }\end{array}$ \\
\hline $\mathrm{C} 1$ & $\varepsilon 2$ in pre-failure region increases with $C 1$. \\
\hline $\mathrm{C} 2$ & $\begin{array}{l}\text { Curvature of stress-strain curve at strength failure point } \\
\text { becomes larger with } \mathrm{C} 2 \text {. }\end{array}$ \\
\hline $\mathrm{C} 31$ & Strength decreases with increase of C31: \\
\hline C32 & Effects of L2 becomes larger with increase of C32. \\
\hline
\end{tabular}
明できるからである．また，式 (5) 右辺第 4 項を追加
Table II. Effects of each parameter on caluculated results. (cf. Fig. 6)

したのは, 強度破壊点以降で応力が強度の半分以下の 部分をより正確に再現するためである.

式 (1)より式 (5)で表される構成方程式には, 10 個 のパラメータが含まれる.この内， $\sigma_{\mathrm{F} 0}$ と $E$ は一軸圧 縮試験より簡単に求まる. 一軸圧縮強度の載荷速度依 存性より $g(\sigma)$ 中の $\delta$ が求まる. $f(\varepsilon 2)$ に含まれる 7 個のパラメータの内, $\mathrm{C} 1$ と $\mathrm{M}$ は強度破壊点以前, $\mathrm{C} 2$ は強度破壊点近傍, C31 と $\mathrm{L} 1$ は強度破壊点以降 の早い時期, 残る $\mathrm{C} 32$ と $\mathrm{L} 2$ は強度破壊点以降の応 力が相当に小さくなった領域の計算結果に最も大きな 影響を及ぼす。この事情を Fig. 6 に示した。また, Table II には各パラメータがどのような影響を及ぼす かを簡単にまとめて示した。

Table III には, こうして求めた 10 個のパラメータ

\begin{tabular}{|c|c|c|c|c|c|c|c|c|c|c|}
\hline & & & $\stackrel{\delta}{\delta}(1 / \mathrm{MPa})$ & $\underset{(1 / \mathrm{sec})}{\mathrm{C} 1}$ & M & $\begin{array}{c}\mathrm{C} 2 \\
(1 / \mathrm{sec})\end{array}$ & $\begin{array}{c}\mathrm{C} 31 \\
(1 / \mathrm{sec})\end{array}$ & L1 & $\begin{array}{c}\mathrm{C} 32 \\
(1 / \mathrm{sec})\end{array}$ & $\mathrm{L} 2$ \\
\hline \multirow[t]{2}{*}{ Inada } & \multirow[t]{2}{*}{ Granite } & Air-dried & 0.23 & $1.0 \times 10^{-4}$ & 10 & $1.0 \times 10$ & $2.0 \times 10^{3}$ & 15 & $2.0 \times 10^{-3}$ & 36 \\
\hline & & Water-saturated & 0.23 & $1.0 \times 10^{-4}$ & 10 & $1.0 \times 10$ & $2.0 \times 10^{4}$ & 15 & $2.0 \times 10^{-3}$ & 36 \\
\hline \multirow[t]{2}{*}{ Kawazu } & \multirow[t]{2}{*}{ Tuff } & Air-dried & 2.00 & $1.0 \times 10^{5}$ & 10 & $1.0 \times 10^{6}$ & $5.0 \times 10^{4}$ & 7 & 1.0 & 36 \\
\hline & & Water-saturated & 1.80 & $5.0 \times 10^{-2}$ & 10 & $5.0 \times 10^{-1}$ & $1.0 \times 10^{-4}$ & 7 & $1.0 \times 10^{-5}$ & 28 \\
\hline \multirow[t]{2}{*}{ Sanjome } & \multirow[t]{2}{*}{ Andesite A } & Air-dried & 0.40 & $1.0 \times 10^{-4}$ & 10 & $1.0 \times 10^{-3}$ & $5.0 \times 10^{-5}$ & 14 & $5.0 \times 10^{-13}$ & 25 \\
\hline & & Water-saturated & 0.40 & $1.0 \times 10^{-3}$ & 10 & $5.0 \times 10^{-4}$ & $5.0 \times 10^{-5}$ & 12 & $1.0 \times 10^{-13}$ & 25 \\
\hline \multirow[t]{3}{*}{ Sanjome } & Andesite B & & & & & & & & & \\
\hline & \multirow[t]{2}{*}{$\mathrm{X}$-direction } & Air-dried & 0.42 & $1.0 \times 10^{-1}$ & 10 & 1.0 & $2.0 \times 10^{-2}$ & 15 & $1.0 \times 10^{-9}$ & 25 \\
\hline & & Water-saturated & 0.41 & $6.0 \times 10^{2}$ & 10 & $6.0 \times 10^{3}$ & $1.0 \times 10$ & 11 & $8.0 \times 10^{-9}$ & 25 \\
\hline & \multirow[t]{2}{*}{$\mathrm{Y}$-direction } & Air-dried & 0.42 & $1.0 \times 10^{-1}$ & 10 & 1.0 & $2.0 \times 10^{-2}$ & 15 & $1.0 \times 10^{-9}$ & 25 \\
\hline & & Water-saturated & 0.42 & $6.0 \times 10^{2}$ & 10 & $6.0 \times 10^{3}$ & $1.0 \times 10$ & 11 & $8.0 \times 10^{-9}$ & 25 \\
\hline & \multirow[t]{2}{*}{$Z$-direction } & Air-dried & 0.42 & 2.0 & 10 & $1.0 \times 10$ & $2.0 \times 10^{-3}$ & 15 & $1.0 \times 10^{-10}$ & 25 \\
\hline & & Water-saturated & 0.40 & $2.5 \times 10^{3}$ & 10 & $9.0 \times 10^{3}$ & $6.0 \times 10^{-1}$ & 13 & $1.0 \times 10^{-10}$ & 25 \\
\hline \multirow[t]{2}{*}{ Tage } & \multirow[t]{2}{*}{ Tuff } & Air-dried & 2.75 & $2.0 \times 10^{-2}$ & 10 & $1.0 \times 10^{-1}$ & $2.0 \times 10^{-5}$ & 13 & $1.0 \times 10^{-14}$ & 25 \\
\hline & & Water-saturated & 2.68 & $2.0 \times 10^{-2}$ & 10 & $1.2 \times 10^{-1}$ & $1.0 \times 10^{-4}$ & 11 & $1.0 \times 10^{-18}$ & 25 \\
\hline \multirow[t]{2}{*}{ Oya } & \multirow[t]{2}{*}{ Tuff } & Air-dried & 3.24 & $1.0 \times 10^{-5}$ & 10 & $1.5 \times 10^{-4}$ & $1.0 \times 10^{-8}$ & 16 & $1.0 \times 10^{-17}$ & 25 \\
\hline & & Water-saturated & 3.26 & $2.0 \times 10^{-3}$ & 10 & $1.0 \times 10^{-2}$ & $1.0 \times 10^{-4}$ & 8 & 0.0 & 25 \\
\hline
\end{tabular}
の值を示すが, この内 C1 と M は応力-ひずみ線図に 及ぼす影響が比較的小さく，一軸圧縮試験より精度良

Table III. Values of parameters in the constitutive equation. 
く求めるのは難しいので, 三城目安山岩については既 報のクリープ実験結果を参考にして決めた. 他の岩石 については，今後クリープ実験を実施し見直す必要が ある。

Fig. 2 とFig. 3 には，Table III に示した值を用いた 計算結果を破線で示した。この構成方程式では, 載荷 速度が 10 倍となった時の強度の増加 $\Delta \sigma$ は $\ln (10) / \delta$ に比例する。したがって, 気乾状態, 湿潤状態を問わ ず同じ $\delta$ を仮定して計算を行なえば，この節の初め に挙げた実験結果(1)と(4)を再現することができる，応 カーひずみ線図の形状を決定するのは， $f(\varepsilon 2)$ の中の 7 個のパラメータである.これらの值は載荷速度には よらないと仮定して計算をおこなった．その結果は，

Fig. 3 よりわかるように, 載荷速度が上昇してもヤン グ率や応力ーひずみ線図の形状はさほど変わらず，載 荷速度の大きい時の応力ーひずみ線図が，小さい時の それを内包する. したがって，(2)と(3)を再現できる. また, 気乾状態と湿潤状態との計算結果を比較して,

（5）も再現できることがわかる. 計算は強度破壊以降 まで問題なく行なわれており，この節の初めに挙げた 要件.6)は満たされていることがわかる：粘弾性挙動 あるいは時間依存性挙動を調べるのにクリープ試験と か応力緩和試験が行なわれる.クリープ試験の場合, 応力は一定に保たれるので, 式 (2)の $\varepsilon 1$ は一定であ $\eta$ ，式(3)を $g(\sigma)$ 一定として計算すればよい。 また, 応力緩和試験の場合には式 (1)の $\varepsilon$ を定として式 (2) と式 (3)を連立させて計算すればよい。このように, 今回使用した構成方程式はクリープ，応力緩和などに も適用可能であり要件 (7)を満たしている. 各パラメ 一夕を求めるには，サーボ式試験機を用いて完全応力 一ひずみ線図を求めると共に, 載荷速度を変えた試験 を行ないその際の強度の増加を求める必要がある. 後 者についてはより簡単に $\Delta \sigma$ あるいは $\delta$ を求める方 法が提案されているが, 要件 (8)のパラメータの求め 方が簡便であることは重要であり今後も検討を加えて 行く必要がある.

$$
5 \text { ま と め }
$$

気乾状態と湿潤状態とでの時間依存性の差異を検討
するために，載荷速度を変えた一軸圧縮試験を行なっ た. 強度, ヤング率ともに気乾状態の方が大きく，気 乾状態の時の応力ーひずみ線図が，湿潤状態の時のそ れを内包することがわかった，他方，載荷速度が増加 すると, 強度は増加するがヤング率はほとんど増加し ない. 載荷状態が 10 倍になった時の強度の増加が, 気乾状態と湿潤状態とで変わらないことは，興味深い． また，この場合も載荷速度の速い時の応力ーひずみ線 四が小さいときのそれを内包する.

以前提案した構成方程式に若干の改良を加え, 実験 結果を再現することを試みた。その結果，気乾，湿潤 状態では, ヤング率 $E$ と強度 $\sigma_{\mathrm{F} 0}$ が変化するが, $\delta$ は変化しないとして計算すれば，実験結果をかなり良 く再現できることがわかった $g(\sigma)$ 中の $\delta$ は，主と して岩石中の初期き裂状態, 長さ, 方向等の関数で, おそらく, き裂先端の応力拡大係数と深い結びつきが あると考えられる. 今後, 気乾状態と湿潤状態とで, $\delta$ の值が変わらないことの意味を, クリープ実験など を追加して検討する必要がある。 また, 湿潤状態の試 験で載荷速度が速いと, 空げき圧が生じ変形・破壊挙 動に影響を及ぼす恐れがあり，この点に関しても今後 検討する必要がある。

\section{参 考 文 献}

1 ) P. S. B. Colback and B. L. Wiid, Proc. 3rd. Can. Rock Mech. Symp., p. 65 (1965).

2 ) V. S. Vutukuri, R. D. Lama and S. S. Saluja, Handbook on Mechanical Properties of Rocks (vol. 1), p. 50 (1974) Trans Teck Publications

3 ) S. H. Kirby, J. Geoph. Res., 89, 3991 (1984).

4 ) O. L. Anderson and P. G. Grew, Reviews Geoph. and Space Physics, 15, 77 (1977)

5 ）大久保誠介, 西松裕一, 日本鉱業会誌, 102, 395 (1986).

6 ）大久保誠介, 西松裕一, 日本鉱業会誌, 100, 1052 (1984).

7 ) S. Okubo, Y. Nishimatsu and C. He, Int. J. Rock Mech. Min. Sci. \& Geomech. Abstr., 27, 559 (1990). 